\title{
Laboratory Test Specimen Condition
}

National Cancer Institute

\section{Source}

National Cancer Institute. Laboratory Test Specimen Condition. NCI Thesaurus. Code C83024.

A characteristic that refers to the physical and org anoleptic state of a laboratory specimen. 